\title{
COMPARATIVE CHARACTERISTIC OF CORRELATION BETWEEN PULSE SUBJECTIVE INDICATORS OF GIRL STUDENTS' AND SCHOOL GIRLS' REACTION TO PHYSICAL LOAD
}

Kozina Z.L. ${ }^{1}$, Iermakov S.S. ${ }^{2}$, Kadutskaya L.A. ${ }^{1}$, Sobyanin F.I. ${ }^{1}$, Krzeminski M. ${ }^{3}$, Sobko I. N. ${ }^{4}$, Ryepko O.A. ${ }^{5}$

${ }^{1}$ National Research University Belgorod State University, Russia

${ }^{2}$ Kazimierz Wielki University in Bydgoszcz, Poland

${ }^{3}$ University of Environmental Sciences, Poland

${ }^{4}$ Kharkov National Economic University, Ukraine.

${ }^{5}$ H.S. Skovoroda Kharkiv National Pedagogical University, Ukraine.

\begin{abstract}
Purpose: to determine characteristics of correlation of girl students' and school girls' subjective and physiological parameters of reaction to physical load. Material: in the research sportswomen of two age groups participated: adult qualified girl students-basketball players $(n=40$, age 20-22years) and junior basketball players ( $n=35$, age12-13years). Registration of heart beats rate was fulfilled with «Polar RS300X». Simultaneously, we registered subjective feeling of loaf value (heaviness) by Borg's method. Results: it was found that in conditions of natural training and competition functioning, with equal heart beats rate values school girls feel tension of fulfilled work subjectively easier. It can be explained by higher maximal values of school girls' heat beats rate, comparing with girls students. Equal values of heart beats rate reflect different changes in girl students' and school girls' organisms. That is why they can not serve reliably informative indicator of load. Conclusions: we determined characteristics of perceived tension under load of game character. It can be connected with emotional tension, which is characteristic for basketball.
\end{abstract}

Key words: load, regulation, basketball, pulse, subjective assessment.

\section{Introduction}

Modern rhythm of life is characterized by high mental and emotional load on children and adults. Especially important physical culture and sports practicing become because they are the main mean of maintaining of organism's functioning and minimal physical activity level [8]. Game kinds of sports are an example of such means. Basketball is one of them [1, 39, 47]. Basketball sets high requirements to functional fitness. Basketball gives load of mixed aerobic-anaerobic character [1, 8, 9]. In this connection application of informative and effective methods of control over organism's functional state acquires great importance. Such approach is required for adequate regulation of physical loads depending on human individual features [23, 35, 37, 44, 47]. It should be noted that determination of adults' and children's reactions to physical load by subjective feelings as well as their physiological parameters becomes very important [8].

From objective physiological indicators of load control heat beats rate is the most informative and accessible in practice as well as relative heart beats rate: heart beats rate, expressed in percents from maximal value [2, 3]. In basketball it is difficult to control physical loads by pulse because it requires many pauses during training session. Besides, it is difficult for a coach to control pulse of all sportswomen simultaneously. Method of subjective control over physical loads by sportswomen themselves is much more convenient and simple [38].

High effectiveness and informative potential of subjective control methods is mentioned in many scientific works [16, 19]. A.A. Ukhtomskiy [19] noted that it is necessary to more seriously consider subjective symptoms of fatigue in practice. They give more delicate and precise criteria of tiredness than existing laboratory methods.

Commonly accepted method of physical loads control by heart beats rate is not sufficiently adequate for physical education tasks. This method provokes many pauses at trainings and does not permit to control load of all sportswomen simultaneously [47-49].

Method of subjective load control by sportswomen themselves is simple and convenient. Effectiveness of this method is based on human feelings and senses. It is rather relevant for the tasks of physical rehabilitation and

(C) Kozina Z.L., lermakov S.S., Kadutskaya L.A.,

Sobyanin F.I., Krzeminski M., Sobko I. N.,

Ryepko O.A., 2016

doi:10.15561/20755279.2016.0403 
basketball trainings. At present time there exists a demand in theoretical and experimental substantiation of this method for physical education tasks at physical culture lessons.

Subjective feelings integrally reflect reality and are a universal device, created by Nature. They are not less objective that commonly accepted indications of instruments. That is why they have right to be scientifically studied alongside with physiological, bio-chemical and other traditionally objective indicators. Feelings are part of human subjective world and accompany any physical work. They help to control physical load and permit to protect organism from inaccessible bio-chemical shifts.

For practical application of scale of load tension subjective assessment it is necessary to regard some its characteristics. In domestic literature rather a few works are devoted to this problem $[13,15]$. The questions of fatigue feeling under different kinds of physical work caused interest in I.M. Sechenov [16] and A.A. Ukhtomskiy [19]. U.M. Sechenov [16] analyzed factors, which cause feeling of fatigue caused by physical work. The author studied physical and physiological fatigue signs in local muscular work. He compared and connected them with subjective feeling of fatigue. In the process of his work he found some interesting facts. A.A.Ukhtomskiy [19] noted that precise quantitative criteria of fatigue can be of practical importance only in exclusively experimental conditions. "Subjective": indications are as objective as any other. For this purpose it is necessary to understand them and interpret correctly. Physiologist knows that any subjective feeling has physical-chemical event in organism in its base.

Feeling of tiredness serves as subjective fatigue indicator. Feeling of tiredness can inform about appearing of defect states in organism much far before they will be detected by clinic or laboratory methods. It is a "natural informer" about starting fatigue. It shall be considered when fulfilling physical work. Otherwise, it can result in sharp decrease of workability. "It is necessary to stop work in due time, when feeling fatigue. It will preserve workability for the future. Not to pay attention to preventive feeling of fatigue means to violate own workability for long period" [19]. It will facilitate more successful application of laboratory results as well as to work out measures for efficient struggle with fatigue.

V.D. Monogarov [13] studied fatigue indicators as objective and subjective indicators in cyclic work (bicycle trainings, work on bicycle ergometer). The author found that between changes in homeostasis, breathing, blood circulation (ensuring oxygen supply) and fatigue subjective symptoms high correlation exists. Besides, it was found that subjective feelings start manifesting themselves some time later $(45-55 \%$ from time of total work period).

V.V. Rosenblat [15] put forward hypothesis that in the base of fatigue feeling there is mainly inhibition processes in centers of cortex motor analyzer. He concludes that inhibition process first starts in cells of cortex motor analyzer. Then this process reflects in mind as a feeling of inner obstacle and wish to stop work. It is called fatigue. Subjectively person feels fatigue in muscle itself. He can exactly determine its localization. V.V. Rosenblat [15] points that subjective and objective are two sides of one phenomenon. In the base of subjective tiredness and objective fatigue one and the same complex of processes in brain exists. That is why any discrepancies between them are impossible. The author also points at need in assessment of fatigue degree and importance of subjective indicators' consideration. In the base of every subjective feeling or sensation there are quite definite objective material processes in nervous apparatuses. Even when assessing work heaviness subjective data can clearly correlate with objective.

Feeling of physical load tension is one of human numerous sensations. That is why it would be logical to assume that dependence of felt tension on different objective values is identical to dependences of other sensations (visual, tactile, taste and etc.). In this connection there appears a problem of determination of sensations' correspondence to surrounding reality. Criterion of our sensations' authenticity is practical activity. To determine the degree of our sensations' correspondence to objective reality is rather difficult. For their quantitative expression special methods are required. At present time some physiological methods have been created for determination of correlations between intensity of different environmental impacts and their perception [24].

One of methods of determination correlation between subjective feelings and objective data is the method of relative scaling. The method implies scale with absolute zero and equal distances between all its marks [24, 25]. For example, the tested drive a car with speed $50 \mathrm{~km}$ per hour. He is asked to reduce speed to value, felt by him as a half of actual. It is repeated several times. This dependence is described by exponential function [38]. 
"Measurement assessment" is one more and more popular example of relative scaling. In this method sportsman receives stimuli of different intensity. He is asked to say their numbers depending on how intensively they are perceived. In this case direct dependence between the felt and actual intensity of a stimulus is often noticed [43].

G. Borg found [25] that equations of these dependences can be functions with indicator of exponent's degree from 0.3 to 3 . It depends on the character of test and conditions of experiment. General form of this equation is the following:

$$
\mathrm{R}=\mathrm{a}+\mathrm{c}(\mathrm{S}-\mathrm{b})^{\mathrm{n}}
$$

where $\mathrm{R}$ is intensity of answer, $\mathrm{S}$ - intensity of stimulus; $\mathrm{a}, \mathrm{b}$ are constants, which show starting points of function, $\mathrm{c}$ - is a constant, characterizing individual features of sportsman and $\mathrm{n}$ - indicator of exponent's degree.

Knowing values $\underline{\mathbf{a}, \mathbf{b}, \mathbf{S}, \mathbf{n}}$ we can calculate $\underline{\mathbf{c}}$. Besides we can predict value $\underline{\mathbf{R}}$ (value of answer to any stimulus).

In other studies specific features of physical loads' perception were found:

- Methods of sportsman's body preparation to pain sensations for determination of their advantages and disadvantages [6];

- Statistically significant distinctions of thresholds of feelings: rotation of forearms and upper limbs in shoulder joints [12];

- It was proved that accuracy of muscular-motor efforts is an individual psycho-motor property and a factor of figure skating elements effectiveness' increase [18];

- Influence of human organism's systemic reactions to psychological rehabilitation impacts with psychoemotional tension [7];

- It was found that sportsmen's condition noticeably changes from discomfort to self confidence and calmness of movements. Then, this state changes through trust to pleasant inner feelings to positive emotional state [14];

- Results of analysis of figure skaters' muscular-motor sensations accuracy are given. A complex of some means is recommended: techniques for increase of muscular sensitivity and accelerated training of figure skating elements [17];

- Special role of kinesthesia in sportsmen's training is regarded. It was determined that this motor sensation to large extent determines accuracy of arbitrary actions' power, time and space characteristics. Motor sensation is regarded as one of main indicators in structure of sportsman's dexterity [50];

- Metrical assessment of correlation between two kinesthesia indicators is provided: coordination and dexterity. The first indicator characterizes inner processes of interaction in nervous-muscular apparatus system (coordination). The second characterizes effectiveness of fulfillment of complex exercise in sportsman's interaction in external conditions of physical education (dexterity) [51].

In our previous works we found:

- High effectiveness, information potential and accessibility of subjective control method for physical loads in schoolchildren's basketball trainings. We shoed adequacy of subjective regulation of physical loafs for the tasks of learning process, connected with development of special endurance in basketball [8];

- We determined that psycho-physiological testing permits for students to choose relevant for them sport specialization for the best realization of personal qualities [10];

- It was found that female volleyball players' individual characteristics depend on a number of other physiological and psycho-physiological indicators. These characteristics confidently differ in players of different game roles $[8,31]$;

- We marked out individual features of sportsmen by condition of their motor abilities. Besides, we found individual styles of qualified sportsmen's duels [32];

- We showed influence of trainings in rope parks on indicators of heart beats rate and on senior schoolchildren's quickness. It was found that overcoming rope obstacles helps to receive required physical load as well as feelings, characteristic for extreme kinds of sports. It was determined that overcoming rope obstacles helps to get rid of fear of difficulties and anxiety before important events [30, 33].

Health indicators are closely connected with subjective sensations. This fact is noted in many scientific works:

- It was found that everyday indicators of subjective age can be markers of health and welfare. It is shown that subjective age can help to find persons with risk of motor restrictions in old age [29, 34, 45]; 
- It was shown that subjective feeling of insomnia are closely connected with bad health and life quality [20];

- It was determined that subjective perception of health and psychological welfare are closely interconnected [26].

In practicing of sports and physical exercises subjective sensations permit to raise the quality of training. It is proved by a number of studies, in which it was determined that:

- Physical exercises play important role in reduction of disability due to diseases and increase subjective opportunities of employment 46];

- Subjective and psychological welfare is achieved with physical exercises. Its level reflects in schoolchildren's progress [27];

- Results of metabolism speed and cardio-respiratory reaction in bicycle riding are compared (two variants) with equal exercises' intensity 21];

- There is deficit of researches with usage of physical activity objective indicators. The authors offer to use subjective sensations for control of physical loads [28];

- Kinetic of physical workability restoration and subjective assessments were compared for football exercises [40].

Thus, with application of the above mentioned methods it is possible to determine interconnection between perceived intensity of any stimulus and its actual value as well as to quantitatively express different sensations and perceptions (for example, perception of physical load tension) [2, 3, 24, 25].

The purpose of the work was to determine characteristics of correlation of girl students' and school girls' subjective and physiological parameters of reaction to physical load.

\section{Material and methods}

Participants: in the research sportswomen of two age groups participated: adult qualified girl studentsbasketball players ( $n=40$, age 20-22years) and junior basketball players ( $n=35$, age12-13years).

All sportswomen gave consent for participation in experiment. For children's participation in experiment we received written consent of parents. The protocol of the research was approved by ethic committee of the university.

Organization of the research: all data were recorded in protocol of the research. The research was conducted in December-March 2015-2016. As the main methods of reaction to physical loads registration we used the following: heart beats rate measurement with monitor of continuous heart beats registration «Polar RS300X». We registered also subjective sensations of load value (heaviness) just after physical load when sportswomen were replaced or in game pauses.

Borg's method was used as pedagogic method of physical loads control [24, 25]. It implies application of special scale of work's heaviness subjective assessment. G. Borg [25] created special digital-verbal scales for qualitative expression of perceived physical load's tension. In the present research we used one of them. This scale is a number of verbal (qualitative) characteristics of load's tension subjective perception (very, very light; very light; light; average; heavy; very heavy; very, very heavy). Quantitative indicators from 6 to 20 correspond to these characteristics. Qualitative verbal characteristics correspond to odd numbers (see table 1).

Borg developed this variant of scale on the base of direct linear interconnection between heart beats rate and subjective assessment of perceived tension. Subjective assessment from 6 to 20 points (for healthy people of 2025 years' age) corresponds to heart beats rate values from 60 to $200 \mathrm{bpm}$. However, there are great individual distinctions in subjective perception of load tension with equal heart beats rate values.

Scale of load tension subjective assessment is used in the following way: when fulfilling physical work, sportsman calls the number on scale, which corresponds his subjective feeling of this load. For example sportsman feels the offered load as "average". By scale "average" load is 13. Therefore sportsman calls number 13. If it is difficult for sportsman to precisely characterize the felt tension he pronounces number between two verbal characteristics (in the supplied example it will be 16). The pronounced by sportsman numbers are recorded in protocol of the researches together with other indicators. If load is not felt as physical tension at all it corresponds to 6 . If load is felt higher than "very, very heavy" number 20 is pronounced. 
Table 1. Scale of subjective assessment of load's heaviness (by G. Borg) [24, 25]

\begin{tabular}{ll}
\hline Digital values of scale & Verbal characteristics of scale \\
\hline 6 & \\
7 & Very, very light \\
8 & \\
9 & Very light \\
10 & \\
11 & Light \\
12 & \\
13 & Average \\
14 & \\
15 & Heavy \\
16 & \\
17 & Very heavy \\
18 & \\
19 & Very, very heavy \\
20 & \\
\hline
\end{tabular}

In this scale quantitative values of subjective sensations approximately correspond to heart beats rate (HBR) HBR $\cdot 10^{-1}$. When using this scale sportsmen call numbers, corresponding their subjective feeling of load's heaviness. High informative potential of this method was substantiated by Borg and other medical scientists [24, 25], эргономике и циклических видов спорта [22]. Besides, effectiveness of this method in female basketball is also shown [8].

Statistical analysis: for every indicator we determined mean arithmetic, mean square deviation S (standard deviation) and variation coefficient (V). Analysis of sample for normal distribution was fulfilled with test $\chi^{2}$. Besides, we applied correlation analysis by Pearson for determination of correlations between physiological and subjective indicators of load's tension (intensity). Presence of correlations was regarded as confident at significance level $\mathrm{p}<0.050 ; 01$ and 0,001 . Coefficients of regression linear equation were calculated: correlations between subjective and physiological load tension indicators for two samples (girl students and schoolgirls). Statistical processing of the received data was fulfilled with Microsoft Ecxcel, SPSS programs.

\section{Results}

Analysis of correlations between subjectively perceived load's tension and heart beats rate by adult and junior female basketball players showed that girl students' heat beats rate frequency varied from 90 to $190 \mathrm{bpm}^{-1}$ just after training or competition loads. The perceived by girl students load value varied from 8 to 16 points. Subjective assessment of load value 11,12,13 and 14 points (see fig.1) corresponded to heart beats rate of 90, 120, 150 and $180 \mathrm{bpm}^{-1}$. Correlation coefficient between heart beats rate and subjective assessment of load value $(\mathrm{n}=341$ measurements) was $0.57(p<0.01)$. Correlation between subjectively perceived load tension and heart beats rate is described with equation of regression:

Where $\mathrm{y}$ is perceived load tension in points;

$$
y=8.11+0.03 x,
$$

$\mathrm{x}$ - frequency of heat beats rate, $\mathrm{bpm}^{-1}$.

For schoolgirls correlation between subjectively perceived load tension and heart beats rate is described by the following equation of regression:

Where $\mathrm{y}$ is perceived load tension in points;

$$
y=8.7+0.024 x,
$$

$\mathrm{x}$ - frequency of heat beats rate, $\mathrm{bpm}^{-1}$.

With equal heart beats rate, girl students' subjectively perceived tension is higher than schoolgirls' one (see 
fig.1).

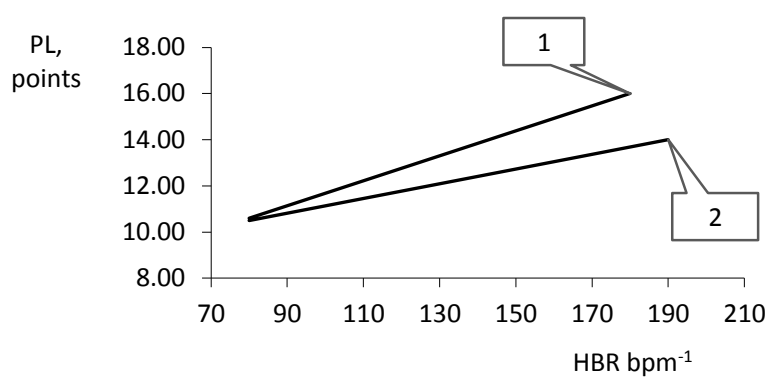

Fig.1. Regression equations of correlation of perceived load tension and heart beats rate: $\mathrm{PL}-$ perceived load value, points; HBR - heart beats rate, $\mathrm{bpm}^{-1} ; 1$ - girl students: $y=8.11+0.03 \mathrm{x}$, where $\mathrm{y}$ is perceived load tension in points and $x$ - frequency of heat beats rate, $b p m^{-1}$. 2- schoolgirls (12-13 years' age): $y=8.7+0.024 x$, where $y$ is perceived load tension in points and $\mathrm{x}-$ frequency of heat beats rate, $\mathrm{bpm}^{-1}$.

This fact witnesses that heart beats rate depends on sportswomen's age: equal heart beats rate reflects different changes in organisms of girl students and schoolgirls. That is why it cannot serve as sufficiently informative indicator of load. At the same time subjectively perceived load tension is more effective indicator of load tension. It can be used in training process of different age basketball players.

\section{Discussion}

The received by us results are proved also in other works [2,3]. High correlation coefficients (between perceived load tension and physiological (physical) load indicators), obtained by us, prove the data of other scientists $[24,25,37 ; 38]$.

G. Borg $[24,25]$ points at presence of intra-individual distinctions of subjective sensations of physical load's heaviness with equal absolute physiological changes in organism. Such distinctions can be determined by age, sex, race, social orientation and other factors.

In our study of correlation between heart beats rate and perceived load tension we found that with equal heart beats rate of girl students their subjective perception of work intensity is higher (see fig.1). Partially it can be explained by higher maximal heart beats rate values in children, comparing with girl students.

We also found that correlation between heart beats rate and perceived load tension obeys to formula HBR $=\mathrm{PL}$ *10 only in the range of heart beats rate from 120 to $160 \mathrm{bpm}^{-1}$. G. Borg [24, 25] pointed at possibility of such deviations from standard formula, when he described 15-points verbal-digital scale.

This peculiarity of the perceived tension under load of game character can be connected with different factors, for example with emotional tension in basketball.

Besides, in basketball player can subconsciously regulate load intensity by him (her) self. It is connected with demand in high accuracy of techniques and operative thinking as well as need in combining these qualities with physical ones: quickness, power, endurance. In conditions of high physical load's intensity accuracy weakens. It is connected with error-resistance. As a result, for maintaining accuracy sportsman reduces load intensity periodically during match. With his restoration, sportsman raises intensity of his actions and keeps this level until he is able to adequately realize tactical and technical actions. The, he reduces intensity again. Such picture is in agreement with hypothesis of Ulmer H. [49] that person has inner control mechanism for distribution of work by time and scope. The author thinks that manifestation of this mechanism is the most characteristic for sports. In sports sportsman' regulation of his load according to his physical potentials and reserves is especially clearly seen. Accordingly sportsman is able to adapt intensity of the fulfilled work. In normal conditions sportsmen are able to avoid excessive fatigue or exhaustion. It permits for them to optimally use workability reserves. Observations of such kind resulted in hypothesis that sportsman has regulation mechanism, controlling distribution of physical work by time and scope. If such mechanism really exists, then exhaustion and overloading are the symptoms of this regulatory mechanism's de-compensation. They are an equivalent of "emergency brake", which prevents from complete loss of workability at the account of forced transition to restoration period. De-compensation of such 
kind takes place, when balance between tension and restoration is violated by external factors [49].

Self-regulation of load in basketball can be an example of this hypothesis realization. Idea about self-regulation of load intensity in basketball corresponds also to general principles of self-organizing systems' operation [4]. Human organism is a self-organizing system, to which such principles are applicable. Application of such principles in sportsman's game functioning permits to conclude that subjectively perceived tension can serve as a kind of regulating factor for load's intensity. With increase of work tension intensity of its subjective perception also increases. In certain point there appears a signal about purposefulness of further load's increase. In this case sportsman subconsciously strives for reduction of load's intensity. It continues until restoration processes complete required compensation. Thus, cyclic increase and decrease of load intensity take place in basketball.

The presence of high positive correlation between subjective and objective indicators of load intensity for different kinds of work also corresponds to theory of P.K. Anokhin [4]. The author applied systemic approach to question about mechanisms of human activity regulation.

It is necessary to consider that subjectively perceived load tension can be influenced by internal (objective, physiological) changes in organism and external (psychic tension, emotional reaction to game, situation in gym) factors. If to follow theory of N.A. Bernstein [5] training in natural conditions is the most emotional. Such training involves great number of hierarchic levels of motor control, comparing with cyclic work on bicycle ergometer. It results in different (to certain extent) perception of load's heaviness, when fulfilling such kinds of work.

Thus, the received by us results are in agreement with theoretical conceptions of P.K. Anokhin [4], N.A. Bernstein [5] and other scientists [8;22;41]. Girl students expressed unanimous desire to train by the offered methodic, referring to higher psychological emancipation with subjective control of load.

\section{Conclusions}

1. The fulfilled by us work showed that in conditions of natural training and competition functioning, with equal heat beats rate values subjectively children perceive the tension of fulfilled work easier than girl students.

2. In basketball players' sport activity heart beats rate depends on age of sportswomen. Actually, equal heart beats rate values do not reflect different changes in organisms of girl students and junior basketball players. That is why it can not be reliably informative indicator of load. Subjectively perceived load tension is more effective indicator of load tension.

\section{References}

1. Ablov AG. Vrachebnye nabliudeniia za basketbolistami [Medical observations over basketball players], Moscow; 1982. (in Russian)

2. Akimov EB, Alekseev VM. Laktat krovi i sub"ektivno vosprinimaemaia napriazhennost' vo vremia myshechnoj raboty raznoj moshchnosti u sportsmenov [Blood lactate and subjectively perceived tension during sporsmen's muscular work of different power]. Mezhdunarodnyj kongress "Sovremennyj Olimpijskij $i$ Paralimpijskij sport $i$ sport dlia vsekh XII" [International congress "Modern Olympic and Para-Olympic sports and sports for all 12"],2008;2:197-198. (in Russian)

3. Akimov EB, Alekseev VM. Effekty producirovaniia sensornoj napriazhennosti vo vremia veloergometricheskoj raboty [Effects of sensor tension's producing in bicycle ergometric work]. Fiziologiia cheloveka, 2008;34(6):125-128. (in Russian)

4. Anokhin PK. Ocherki po fiziologii funkcional'nykh sistem [Essays on physiology of functional systems], Moscow: Medicine; 1975. (in Russian)

5. Bernshtejn NA. O postroenii dvizhenij [On building of movements], Moscow: Medicine; 1947. (in Russian)

6. Grishin AA. Eksperimental'noe issledovanie podgotovki udarnoj poverkhnosti goleni $\mathrm{k}$ bolevym oshchushcheniiam v kikboksinge [Experimental study of training of kicking shin surface to pain feeling in kickboxing]. Uchenye zapiski universiteta im. P.F. Lesgafta, 2015;10(128):49-53. (in Russian)

7. Klassina SIa. Psikhologicheskie vozdejstviia kak sredstvo reabilitacii funkcional'nogo sostoianiia cheloveka pri psikhoemocional'nom napriazhenii [Psychological impacts as rehabilitation mean for human functional state in case of psycho-emotional tension]. Vestnik novykh medicinskikh tekhnologij, 2014;1:77-78. (in Russian)

8. Kozina ZL, Iermakov SS, Jagiello M. Application of yoga in physical rehabilitation joint and muscle flexibility in women 35-45 years. Physical Education of Students, 2011;4:37-44. 
9. Kozina ZL. Rezul'taty razrabotki i primeneniia universal'nykh metodik individualizacii uchebnotrenirovochnogo processa v sportivnykh igrakh [Results of working out and application of universal methodic for individualization of training process in sport games]. Slobozhans'kij naukovo-sportivnij visnik, 2008;3:7379. (in Russian)

10. Barybina LN, Kozina ZL. Description of psychophysiological indexes of students of different sporting specializations. Physical Education of Students, 2010;4:6-12.

11. Kozina ZL. Faktorni modeli fizichnoi pidgotovlenosti volejbolistok visokogo klasu riznogo igrovogo amplua [Factorial models of different game roles' elite female volleyball players' fitness]. Pedagogics, psychology, medical-biological problems of physical training and sports, 2007;9:80-85.

12. Korol'kov AN, Ol'khovikova KO. Tochnost' oshchushcheniia dvizhenij pronacii-supinacii svobodnykh verkhnikh konechnostej [Preciseness of motor sensation - pronation, supination of upper limbs]. Izvestiia Tul'skogo gosudarstvennogo universiteta, 2014;4:95-100. (in Russian)

13. Monogarov VD. Genez utomleniia pri napriazhennoj myshechnoj deiatel'nosti [Genesis of fatigue in case of tensed muscular functioning]. Nauka v olimpijskom sporte, 1994;1:47-57. (in Russian)

14. Plotnyj AR. Samoreguliaciia dejstvij tennisistov vysokoj kvalifikacii na osnove treninga "tennis - pozitiv + " [Self-regulation of elite tennis-players' actions on the base of training "tennis-positive +"]. Uchenye zapiski universiteta im. P.F. Lesgafta, 2015;2(120):220-224. (in Russian)

15. Rozenblat VV. Problema utomleniia [The problem of fatigue], Moscow: Medicine; 1975. (in Russian)

16. Sechenov IM. K voprosu v vliianii razdrazheniia chustvuiushchikh nervov na myshechnuiu rabotu cheloveka [On the question of influence of sensing nervous irritation on human muscular work], USSR Academy of Sciences; 1956. (in Russian)

17. Tugunova IaP. Povyshenie effektivnosti processa obucheniia iunykh figuristov s ispol'zovaniem special'no podobrannykh sredstv [Rising of junior figure skaters' training process effectiveness with the help of specially selected means]. Uchenye zapiski universiteta im. P.F. Lesgafta, 2014;4(110):171-175. (in Russian)

18. Tugunova IaP, Klopov AIu. Tochnost' myshechno-dvigatel'nykh oshchushchenij kak faktor povysheniia urovnia vypolneniia elementov figurnogo kataniia [Preciseness of muscular motor sensations as factor, increasing quality of figure skating elements' fulfillment]. Uchenye zapiski universiteta im. P.F. Lesgafta, 2014;6(112):189-194. (in Russian)

19. Ukhtomskij AA. Fiziologiia dvigatel'nogo apparata [Physiology of motor apparatus], Leningrad; 1927. (in Russian)

20. Aritake S, Asaoka S, Kagimura T, Shimura A, Futenma K, Komada Y, Inoue Y. Internet-Based Survey of Factors Associated with Subjective Feeling of Insomnia, Depression, and Low Health-Related Quality of Life Among Japanese Adults with Sleep Difficulty. International journal of behavioral medicine, 2015;22(2):233238. doi: 10.1007/s12529-014-9421-7

21. Bakkum AJT, de Groot S, Onderwater MQ, de Jong J, Janssen TWJ. Metabolic rate and cardiorespiratory response during hybrid cycling versus handcycling at equal subjective exercise intensity levels in people with spinal cord injury. Journal of spinal cord medicine, 2014;37(6):758-764. doi: 10.1179/2045772313Y.0000000164

22. Baskevich OV. Interconnection of students' somatic type with somatic health. Physical Education of Students, 2015;6:4-9. doi:10.15561/20755279.2015.0601

23. Bolyak AA, Pomazan AA. Parameters of effective competition activity and selection of young gymnasts in age 9-10 years. Pedagogics, psychology, medical-biological problems of physical training and sports, 2014;4:3-7. doi:10.6084/m9.figshare.951919

24. Borg G. Psychophysical bases of percieved exertion. Medicine and Science in Sports and Exercise, 1982;14:377-381.

25. Borg G. Borg's perceived exertion and pain scales. Champaign, IL, US: Human Kinetics; 1998.

26. Choi Namkee G, DiNitto Diana M, Kim Jinseok. Discrepancy Between Chronological Age and Felt Age Age Group Difference in Objective and Subjective Health as Correlates. Journal of aging and health, 2014;26(3):458-473. doi:10.1177/0898264314523449 
27. Garcia D, Jimmefors A, Mousavi F, Adrianson L, Rosenberg P, Archer T. Self-regulatory mode (locomotion and assessment), well-being (subjective and psychological), and exercise behavior (frequency and intensity) in relation to high school pupils' academic achievement. Peerj. 2015;4:847-850. doi:10.7717/peerj.847

28. Gerber M, Brand S, Herrmann C, Colledge F, Holsboer-Trachsler E, Puhse U. Increased objectively assessed vigorous-intensity exercise is associated with reduced stress, increased mental health and good objective and subjective sleep in young adults. Physiology \& behavior, 2014;135:17-24. doi:10.1016/j.physbeh.2014.05.047

29. Kotter-Gruhn D, Neupert SD, Stephan Y. Feeling old today? Daily health, stressors, and affect explain dayto-day variability in subjective age. Psychology \& health, 2015;30(12):1470-1485. doi: 10.1080/08870446.2015.1061130

30. Kozina ZhL, Antonov OV, Kozin SV, Grin LV. Changing the functional state of the pupils of high classes during the passage of obstacles rope park. Physical Education of Students, 2012;3:61-66.

31. Kozina $\mathrm{ZhL}$, Iermakov SS, Pogorelova AO. The methodological basis for determining individual characteristics of volleyball players at the stage of basic training specialist. Physical Education of Students, 2012;3:53-60.

32. Kozina ZL, Jagiello Wladyslaw, Jagiello Marina. Determination of sportsmen's individual characteristics with the help of mathematical simulation and methods of multi-dimensional analysis. Pedagogics, psychology, medical-biological problems of physical training and sports, 2015;12:41-50. doi:10.15561/18189172.2015.1207

33. Kozina ZhL, Kozin SV, Antonov OV, Grin LV. Ropes parks as a way of increase of the motor activity of students. Physical Education of Students, 2011;6:40-44.

34. Kunze F, Raes AML, Bruch H. It Matters How Old You Feel: Antecedents and Performance Consequences of Average Relative Subjective Age in Organizations. Journal of applied psychology, 2015;100(5):15111526. doi: 10.1037/a0038909

35. Levchenko VA. Indexes of hemodynamics in a dosage of physical activity in girls against the background of low systolic blood pressure. Pedagogics, psychology, medical-biological problems of physical training and sports, 2015;2:43-46. doi:10.15561/18189172.2015.0207

36. Liu Yong Qiang. Operative correction of judoists' training loads on the base of on-line monitoring of heart beats rate. Physical Education of Students, 2015;2:13-21. doi:10.15561/20755279.2015.0203

37. Makuts TB, Vysochina NL. Factorial analysis of tennis players' psychological and technical-tactic fitness at the stage of specialized basic training. Pedagogics, psychology, medical-biological problems of physical training and sports, 2015;9:45-50. doi:10.15561/18189172.2015.0907

38. Marcora S, Staiano W. The limit to exercise tolerance in humans: mind over muscle? European Journal of Applied Physiology, 2010;109(4):763-770.

39. Kozina Z, Repko O, Ionova O, Boychuk Y, Korobeinik V. Mathematical basis for the integral development of strength, speed and endurance in sports with complex manifestation of physical qualities. Journal of Physical Education and Sport, 2016;16(1):789-792. doi:10.7752/jpes.2016.01012

40. Nedelec M, McCall A, Carling C, Le Gall F, Berthoin S, Dupont G. Physical performance and subjective ratings after a soccer-specific exercise simulation: Comparison of natural grass versus artificial turf. Journal of sports sciences, 2013;31(5):529-536. doi:10.1080/02640414.2012.738923

41. Ohromiy GV, Makarova NU, Kasyuha AM. Psychophysiological methods and criteria for the selection of individual metered loads in athletes of taekwondo section. Physical Education of Students, 2014;6:54-62. doi: $10.15561 / 20755279.2014 .0611$

42. Kovářová Lenka, Pánek David, Kovář Karel, Hlinčík Zdeněk. Relationship between subjectively perceived exertion and objective loading in trained athletes and non-athletes. Journal of Physical Education and Sport, 2015;15(2):186-193. doi:10.7752/jpes.2015.02029

43. Thirer J, Knowlton R, Sawka M, Chang TJ.elationship of psychophysiological characteristics to perceived exertion and levels of anxiety in competitive swimmers. Journal of Sport Behavior, 1978;1(4):169-173.

44. Rovniy AS, Lastochkin VM. Mechanisms of adaptation to intensive loads of 400 meters' hurdles runners at stage of initial basic training. Physical Education of Students, 2015;4:39-43. 
doi:10.15561/20755279.2015.0406

45. Stephan Y, Sutin AR, Angelina R, Terracciano A. "Feeling younger, walking faster": subjective age and walking speed in older adults. Age, 2015;37(5):100-120. doi: 10.1007/s11357-015-9830-9

46. Storm V, Paech J, Ziegelmann JP, Lippke S. Physical exercise, sickness absence and subjective employability: an 8-year longitudinal observational study among musculoskeletal patients. Journal of rehabilitation medicine. 2016;48(6):541-546. doi:10.2340/16501977-2103

47. Zhanneta K, Irina S, Tatyana B, Olena R, Olena L, Anna I. The applying of the concept of individualization in sport. Journal of Physical Education and Sport, 2015;15(2):172-177. doi:10.7752/jpes.2015.02027

48. Abdolrahman Najafi, Saeid Shakerian, Abdolhamid Habibi, Mehrzad Shabani, Rouholah Fatemi. The comparison of some anthropometric, body composition indexes and VO2max of Ahwaz elite soccer players of different playing positions. Pedagogics, psychology, medical-biological problems of physical training and sports, 2015;9:64-68. doi:10.15561/18189172.2015.0910

49. Ulmer H-V. Perceived exertion as part of emoyion beharioral feedback system for arrangement of strain during exercise. Archpig. Rada. Toksikol. 1979;330(3):1143-1145.

50. Zaporozhanov VA. About reliable indicator of proprioception in agility control. Pedagogics, psychology, medical-biological problems of physical training and sports, 2013;4:21-25. doi:10.6084/m9.figshare.693023

51. Zaporozhanov VA, Boraczynski T. Discussion on the concepts of "coordination" and "agility" in terms of physical education. Pedagogics, psychology, medical-biological problems of physical training and sports, 2015;3:15-19. doi:10.15561/18189172.2015.0303 


\section{Information about the authors:}

Kozina Z.L.; http://orcid.org/0000-0001-5588-4825; Zhanneta.kozina@gmail.com; National Research University Belgorod State University; Pobeda 85, Belgorod, 308015, Russia.

lermakov S.S.; http://orcid.org/0000-0002-5039-4517; sportart@gmail.com; Kazimierz Wielki University in Bydgoszcz; Sport str. 2, of.209, 85-064 Bydgoszcz, Poland.

Kadutskaya L.A.; http://orcid.org/0000-0003-1812-6915; kadutskaya@bsu.edu.ru; National Research University Belgorod State University; Pobeda 85, Belgorod, 308015, Russia.

Sobyanin F.I.; http://orcid.org/0000-0001-7316-8355; sobyanin@bsu.edu.ru; National Research University Belgorod State University; Pobeda 85, Belgorod, 308015, Russia.

Krzeminski Marek; http://orcid.org/0000-0003-1939-4399; marekkrzem@interia.pl; University of Environmental Sciences; ul. Zubrzyckiego 6, 26-600 Radom, Poland.

Sobko I. N.; http://orcid.org/0000-0002-4920-9775; sobko.kh@mail.ru; Kharkov National Economic University; Lenina boulevard 9a, 61001, Kharkov, Ukraine.

Ryepko O.A.; http://orcid.org/0000-0001-6879-6015; Zhanneta.kozina@gmail.com; H.S. Skovoroda Kharkiv National Pedagogical University; Artema str. 29, Kharkov, 61002, Ukraine.

Cite this article as: Kozina Z.L., Iermakov S.S., Kadutskaya L.A., Sobyanin F.I., Krzeminski M., Sobko I.N., Ryepko O.A. Comparative characteristic of correlation between pulse subjective indicators of girl students' and school girls' reaction to physical load. Physical education of students, 2016;4:24-34. doi:10.15561/20755279.2016.0403

The electronic version of this article is the complete one and can be found online at: http://www.sportpedu.org.ua/html/arhive-e.html

This is an Open Access article distributed under the terms of the Creative Commons Attribution License, which permits unrestricted use, distribution, and reproduction in any medium, provided the original work is properly cited (http://creativecommons.org/licenses/by/4.0/deed.en).

Received: 05.08.2016

Accepted: 19.08.2016; Published: 28.08.2016 